\title{
The Role of Cosmetic Gynecology Treatments in Women in Perimenopausal Period
}

\author{
Anna Galęba',2, Beata Bajurna1, Jerzy T. Marcinkowski1 \\ ${ }^{1}$ Department of Social Medicine, Poznan University of Medical Sciences, Poznan, Poland \\ ${ }^{2}$ Private Practice of Aesthetic Medicine and Anti-Aging in Warszawa and Poznan, Poland \\ Email: jtmarcin@gmail.com
}

Received 9 February 2015; accepted 23 February 2015; published 27 February 2015

Copyright (C) 2015 by authors and Scientific Research Publishing Inc.

This work is licensed under the Creative Commons Attribution International License (CC BY). http://creativecommons.org/licenses/by/4.0/

cc) (7) Open Access

\section{Abstract}

The conditions in which we live nowadays contribute to exposure of our bodies to harmful factors such as UV radiation, pollution, smoking, poor eating habits, low physical activity, stress, which thereafter lead to the acceleration of skin aging process. In women, the process is additionally dependent on the menopause, as a result of the disappearance of hormones, the process is faster. Physiological changes that occur in women's body during perimenopausal and menopausal period affect their sexual function: pain during an intercourse, decreased libido, lack of agitation. Deficiency of hormones, besides skin changes, leads to vaginal dryness, accompanied by inflammation, often correlated with discharge and burning. As a result of the loss of hyaluronic acid labia become slack and less moisturized. In addition, there has been observed: a gradual loss of pigment and hair, involution of the clitoris, and involution and sticking of labia minora, lipoatrophy of labia majora with subsequent reduction in their volume and thinning the lining around the vaginal opening. This article presents processes of skin aging. It describes mechanisms of intrinsic and extrinsic aging. It also presents the mechanisms of accelerated aging in women in perimenopausal period-accelerated skin aging dependent on hormonal factors associated with the loss of ovarian function. The research presents how the hormonal loss influences woman's body, her genitals-its functionality and aesthetic look. It also shows how using filler treatments in gynecology can restore the aesthetic appearance of female genital and improve their functionality.

\section{Keywords}

Menopause, Perimenopausal Period, Cosmetic Gynecology, Cosmetic Medicine, Aesthetic Medicine, Aging of the Skin 


\section{Introduction}

There has always been a desire to be beautiful and attractive, but nowadays it is more distinct than ever. The conditions in which we live nowadays contribute to exposure of our bodies to many harmful factors. It is worth mentioning: UV radiation, pollution, smoking, poor eating habits, poor physical activity and so on. These factors combined with stress, to which we have been exposed from an early age, all together harm our body and mainly contribute to fast ageing of the skin. In women, the process also depends on menopause. Owing to the reduction in ovarian functionality the loss of collagen, hyaluronic acid, elastin, capillaries and subcutaneous adipose tissue, is even more severe. As a result of these changes, skin becomes drier, rougher, less hydrated, less firm and tight, resulting in much faster deepening of wrinkles, furrows and folds. Changes also occur in the genital area, including not only the loss of functionality but also the aesthetic look [1].

Ageing process affects not only the skin but the whole body. Physicians of all specialties care about the health of patients in a complex manner. The treatments, chosen by patients who take advantage of services provided by aesthetic medicine and anti-aging doctors, eventually affect the quality of their lives. These treatments boost their self-confidence and improve their well-being and vitality. The treatments are enjoyed by female patients of all ages. The treatments have primarily a preventive measure, that is why they should be started fairly early (since about 25 years of age), but they are also therapeutic, that is the reason why they are so popular among older patients [1]. Female patients not only correct the aesthetics of their exposed body parts, including face, neck, cleavage, hands, and the whole body, but also they more frequently visit aesthetic gynecologist in order to correct aesthetics of their intimate area or to improve functionality of the genital area [2].

This article presents processes of skin aging. It describes mechanisms of intrinsic and extrinsic aging. It also presents the mechanisms of accelerated aging in women in perimenopausal period-accelerated skin aging dependent on hormonal factors associated with the loss of ovarian function. The research presents how the hormonal loss influences woman's body, her genitals-its functionality and aesthetic look. It also shows how using filler treatments in gynecology can restore the aesthetic appearance of female genital and improve their functionality.

\section{The Skin Aging}

The impact on the process of aging of our body as a whole, have both internal and external factors. Genes are responsible for the speed in which a progress in aging processes takes place, and in which there start to appear the first signs of aging. The rate of aging is dependent on many external factors such as: the nature of work, climatic conditions and also the rhythm of individual exploitation, however the greatest impact of exogenous factors is attributed to: exposure to UV rays, smoking, poor nutrition and intoxicants (such as alcohol, excessive coffee) [3]-[5].

Skin aging is divided into [1] [4] [6] [7]: chronological aging (physiological aging) and non-chronological aging (photoaging), or the skin aging is divided into: intrinsic aging-the proper one, genetic (intrinsic) and extrinsic aging-improper (extrinsic).

Intrinsic aging (the proper one) [1] [4] [7] [8] is an unavoidable process, it progresses over time and it is impossible to stop. As a result of the proper, intrinsic aging there occur; atrophy of the epidermis and dermis (skin thickness decreases with age of about $20 \%$, only the thickness of the stratum corneum does not change with age), decrease in number of fibroblasts and mast cells in the epidermis. In young skin, collagen is laid in the skin in a regular grid pattern; inaging skin collagen is arranged in bundles giving the impression of disorder [6] [9]. Also there is fragmentation and calcification of elastic fibers and their degradation (due to increased amounts of the metalloproteinase enzyme in the cell matrix), and also the accumulation of material containing malformed elastin in the papillary and reticular layer of the skin (elastin in aging skin contains small amounts of sugars and lipids and significantly increased levels of amino acids) [1] [4] [8].

With time, there are changes within the dermal-epidermal DEJ area (dermal-epidermal junction), which gets flattened (impairment in the nutrients exchange between the derma and the epidermis is its consequence). Within the dermal-epidermal junction DEJ, the amount of collagen type IV and type VII decreases which leads to thinning of the layer and, consequently, to the formation of wrinkles [9].

The turn over time (TOT-Turn Over Time) of cells within epidermis is also extended. Between third, and forth decade of life this time may be extended by $30 \%-50 \%$, while for the 20 -year-old the cell transit through a spinous layer takes 20 days, for 40 - 50 years old this time is extended to 30 days, and even longer. The consequence of extended TOT is [1] [6]: thinning of the epidermis, slower wound healing and less effective exfolia- 
tion.

Hyaluronic acid (HA) has properties that allow binding water that has a volume of one thousand times the volume of its particle; this allows the skin to maintain the water-electrolyte balance. In young skin, HA exists on the periphery of collagen and elastin; however in significantly aging skin such connections disappear. The consequences of the decrease of collagen, elastin and HA in the skin include: the appearance of wrinkles, formation of furrows, loose skin, and dry skin [1] [4] [8].

Dry, exfoliating skin is an indicator of skin aging. The reason for this is the deterioration or disappearance of functional skin barrier due to reduced amounts of lipids and increased water loss through the skin (trans-epidermal water loss-TEWL). With age there is also a decrease in the amount of subcutaneous fat (mainly of the face, the dorsal surface of the hands and the stanchions), and disappearance of melanocytes on average of $8 \%$ $20 \%$ in every 10 years (clinical condition is manifested by reduction in the number of melanocytic marks in the elderly, and thus reducing the amount of melanin in the skin, in connection with the protective action of melanin - it absorbs carcinogenic UV rays, the elderly are more susceptible to the formation of skin cancer) [1] [4] [8] [10].

As a result of intrinsic skin aging the skin vascularization also deteriorates. The reduction in vascularization in aging skin can be as high as $35 \%$. It is particularly notable in the papillary layer of skin where there is a loss of vertical vascular loops which leads to: a reduced blood flow, reduction in nutrients supply to skin, thermoregulation disorders, lowering the temperature of the surface of the skin and skin paleness [11].

As a result of intrinsic aging, telomeres get shortened with age. It has been proven that the natural and progressive shortening of telomeres is the most important mechanism of skin cell aging. They also block the process of damaging cells by free radicals. Shortening of telomeres associated with aging reflects in tissue dwindling [12].

Among women, the aging of the skin is additionally dependent on the menopause that is one of the hormonal factors associated with the loss of ovarian function. There is a decrease in estrogen production (specifically 17 beta-estradiol), which contributes to changes in the epidermis, dermis and subcutaneous tissue. Estrogen deficiency contributes to: reduction of the amount of collagen, which amount decreases rapidly especially in the first five years after the menopause (around 30\%), it relates to both collagen types I and III. This leads to a decrease in the thickness of skin, loss of elasticity and tension. As a result of hormonal changes there is a decrease in an activity of sebaceous and sweat glands (dry, rough skin), and also there is a decrease in the level of: hyaluronic acid, elastin fibers, capillaries and subcutaneous tissue disappears [1] [7] [13]-[16].

Extrinsic aging-improper [1] [4]-[8] [17] [18].

Extrinsic aging is premature and relates primarily to skin. It may be prevented. The main role among exogenous factors is attributed to smoking, poor nutrition, and exposure to UV rays. Exposure to UV radiation is responsible for $80 \%$ of aging of face dermis and other exposed parts of the body. UVA rays penetrate deeply into the tissue and cause immune suppression and premature aging of the skin, are responsible for the formation of free radicals and phototoxic and photoallergic reactions. UVB rays penetrate to the deepest layers of the epidermis, damage cell DNA, are responsible for the burning of the skin and stimulate carcinogenesis. The consequences of exposure to UV radiation include: formation of sunburn cells, increased production of collagenase, the induction of inflammation, damages of telomeres, photocarcinogenesis, photoimmunosuppression and photoaging.

\section{Cosmetic Gynecology and Perimenopausal Period}

Aesthetic medicine is a branch of medicine that deals with the construction and reconstruction of human psychophysical balance. It is a medicine that values the quality of life, and health is regarded here as a sign of good mental and physical condition. This is a branch of medicine primarily with a proactive character (preventive), and then reconstructive, or corrective. Aesthetic medicine is a branch of medicine that deals with patients' health in the aspect of: appearance, image, aesthetics, well-being, noticeable changes to the skin, and sensible discomfort in the quality of patient's life [1]. It has been shown that the symptoms of perimenopausal period significantly influence the worsening of the quality of women's life, particularly in the aspect of psychic, social and sexual functioning [19] [20].

Doctors, thanks to aesthetic medicine, contribute to improvement of patient's appearance, who, as a result of that often regains mental stability and greater self-confidence [1]. Female patients more often visit doctors who 
provide treatments in rejuvenation of the female genitals, not only for aesthetic reasons but also for functional [2].

Physiological changes that occur in women during premenopausal and menopausal period, often affects women's sexual function, such as pain during intercourse, decreased libido or lack of agitation [21] [24]. Reduction in the concentration of hormones, especially estrogen and androgen is considered to be the cause of sexual dysfunctions in this period. Reduction in the levels of estrogen contributes to a decrease in frequency of intercourses, and the lack of testosterone decreases interest in sexual life. Hormone deficiency, in addition to changes in the skin leads to faster drying of mucus, making it more susceptible to injury. It is manifested by dryness in the vagina. When there is not enough mucus in the vagina, intercourse can cause pain and abrasions. There are often incidents of infections. Therefore, vaginal dryness is accompanied by inflammation, associated with discharge and burning. As a result of the loss of hyaluronic acid labia become slack and less moisturized. Loss of collagen contributes to the thinning of the skin around the genitals. The vagina loses elasticity and is more easily irritated. In addition, there has been observed: a gradual loss of pigment and hair, involution of the clitoris, and involution and sticking of labia minora, lipoatrophy of labia majora with subsequent reduction in their volume and thinning the lining around the vaginal opening [21]-[23] [25].

\section{Fillers Treatments in Cosmetic Gynecology}

Tissue Fillers are used not only for aesthetic purposes in the face but also in other areas, including the pubic area. In aesthetic gynecology there are used two types of fillers based on hyaluronic acid. These are single-phase fillers, developed in special technology (IPN-like), thanks to which the injected gel is more resistant to hyaluronidase and free radicals. In addition, there is an increased comfort for the patient during the administration of this substance. One of these is applied mainly in women of reproductive age or premenopausal women who complain on dryness, sensitivity and irritation of the vulva. The product is administered intradermally into the labia majora and labia minora, so that the proper hydration and nutrition of tissues is recovered. The second substance is mostly recommended to patients who are perimenopausal or menopausal who suffer from hypotrophy of labia majora (to a lesser or greater extent) in order to restore normal volume of labiamajora and pubis. In these cases, the cross-linked hyaluronic acid is administered subcutaneously. Hyaluronic acid firstly restores proper volume of the labiamajora and pubis; secondly it leads to the activation of fibroblasts and what is related to it, with time to the production of collagen, elastin and hyaluronic acid which restores the correct tension and hydration of the skin of this area [26].

\section{Summation}

Female patients in perimenopausal and menopausal period due to hormonal changes are more likely to experience changes in their appearance from the aesthetic aspect. With age women much faster lose collagen, elastin, hyaluronic acid and capillaries. The skin becomes less tense, less hydrated and less nourished, rougher and drier. Deepening of facial wrinkles, furrows and folds occurs much faster. As a result of the disappearance of the subcutaneous tissue, the dorsal surface of hands and neck looks old. An activity of the sebaceous glands and sweat glands decreases. Changes also occur in the genital area. The labia become flaccid and less moist. Vagina loses its elasticity and becomes drier, and is more susceptible to injury. These changes often interfere with women's sexual functions, who feel pain during a sexual intercourse. Treatments in aesthetic medicine lead to improvement in patient's appearance. Therefore their quality of life improves. In addition to appearance, treatments like treatments in aesthetic gynecology impact the functionality of the patient. They not only make the labia and pubis look better, more aesthetically, but also improve vaginal and labia lubrication so that patient feels no discomfort during sexual intercourse. Aesthetic Gynecology is the branch of medicine that increasingly develops in Poland and increasingly arouses interest among women.

\section{References}

[1] Galęba, A. (2011) Evaluation of Quality Life of Patients before and after Selected Treatments from Aesthetic Medicine. Doctoral Dissertation, Poznan University of Medical Sciences, Poznan.

[2] Ishii, C.H. (2013) Book Review: Be Your Best: A Comprehensive Guide to Aesthetic Plastic Surgery, Written by the Experts. Aesthetic Surgery Journal, 33, NP5-6. http://dx.doi.org/10.1177/1090820X12467791

[3] Cunningham, M.R., Roberts, R., Barnbee, A.P., Druen, P.B. and Wu, C. (1995) Their Ideas of Beauty Are on the 
Whole, the Same as Ours. Consistency and Variability in the Cross-Cultural Percepcion of Female Physical Attractivess. Journal of Personality and Social Psychology, 261-279. http://dx.doi.org/10.1037/0022-3514.68.2.261

[4] Baumann, L. (2007) Skin Ageing and Its Treatment. The Journal of Pathology, 211, 241-251. http://dx.doi.org/10.1002/path.2098

[5] Wojas-Pelc, Sułowicz, J. and Nastałek, M. (2008) Promieniowanie ultrafioletowe, dym tytoniowy i estrogeny ścieżek wpływ na starzenie się skóry; możliwości zapobiegania. Przegląd Lekarski, 862-866.

[6] Adamski, Z. and Kaszuba, A. (2008) Dermatology for Cosmetologists. Scientific Publishing University of Medical Sciences in Poznan, Poznan, 228-233, 332-340.

[7] Galęba, A., Bajurna, B. and Shankar, S. (2014) Premature Skin Aging-A Process That Can Be Slowed Down by Appropriate Prevention. Hygeia Public Health, 49, 708-711.

[8] Chung, J.H. and Eun, H.C. (2007) Angiogenesis in Skin Aging and Photoaging. Journal of Dermatology, 593-600. http://dx.doi.org/10.1111/j.1346-8138.2007.00341.x

[9] Orentreich, N. and Selmanowitz, V.J. (1969) Levels of Biological Functions with Aging. Transactions of the New York Academy of Sciences, 992. http://dx.doi.org/10.1111/j.2164-0947.1969.tb02020.x

[10] Kubia, M. and Rotsztejn, H. (2012) Effects of Hormonal Changes in Women on Skin Pigmentation. Przegl Menopauz, 3, 228-232.

[11] Passeron, T. and Ortonne, J.P. (2003) Skin Ageing and Its Prevention. Presse Médicale, 32, 1474-1482.

[12] The Nobel Prize in Physiology or Medicine 2009. Nobelprize org. http://nobelprize.org/nobel_prizes/medicine/laureates/2009/

[13] Galęba, A. (2010) Mesotherapy Is a Way of Skin Biorevitalisation. Dermatologia Estetyczna, 34-40.

[14] Derwich, K. and Pawelczyk, L. (2001) Klimakterium. Położnictwo i ginekologia pod red. Pisarskiego, T., Wydawnictwo Lekarskie PZWL, Warszawa. Wydanie IV unowocześnione, 245-250.

[15] Galęba, A. and Bajurna, B. (2009) Premature Skin Aging-A Process Which Can Be Prevented. Polish Nursing, 5557.

[16] Makrantonaki, E. and Zouboulis, C.C. (2007) The Skin as a Mirror of the Aging Process in the Human OrganismState of the Art and Results of the Aging Research in the German National Genome Research Network 2 (NGFN-2). Niemiecka Centrala GenomeResearch Network 2, Experimental Gerontology, 42, 879-886. http://dx.doi.org/10.1016/j.exger.2007.07.002

[17] Calleja-Agius, J., Muscat-Baron, Y. and Brincat, M.P. (2007) Skin Ageing. Menopause International, 13, 60-64.

[18] Rabe, J.H., Mamelak, A.J., McElgunn, P.J., Morison, W.L. and Sauder, D.N. (2006) Photoaging: Mechanisms and Repair. Journal of the American Academy of Dermatology, 55, 1-19. http://dx.doi.org/10.1016/j.jaad.2005.05.010

[19] Barnaś, E., Krupińska, A., Kraśnianin, E. and Raś, R. (2012) Psychosocial and Occupational Functioning of Women in Menopause. Przegląd Menopauzalny, 4, 296-304.

[20] Nusrat, N. and Achmed Sohoo, N. (2010) Severity of Menopausal Symptoms and the Quality of Life at Different Status of Menopause: A Community Based Survey from Rural Sindh, Pakistan. International Journal of Collaborative Research on Internal Medicine \& Public Health, 2, 118-130.

[21] Skrzypulec-Plinta, V., Drosdzol-Cop, A. and Skwara-Guzikowska, K. (2013) A Healthy Vagina during MenopauseJust Only Estrogen? Przegląd Menopauzalny, 1, 4042.

[22] Skrzypulec, V. (2010) Seksualność kobiet w okresie klimakterium. W: Lew-Starowicz, Z., Skrzypulec, V., (red.). Podstawy seksuologii. Wydawnictwo Lekarskie PZWL, Warszawa; 138-145.

[23] Jakiel, G., Pilewska-Kozak, A.B., Łepecka-Klusek, C., Tkaczuk-Włach, J. and Syty, K. (2009) Mężczyźni kobiet menopauzalnych. Część II. Relacje partnerskie i seksualne. Przegląd Menopauzalny, 2, 97-101.

[24] Schnatz, P.F., Whitehurst, S.K. and O’Sullivan, D.M. (2010) Sexual Dysfunction, Depression, and Anxiety among Patients of an Inner-City Menopause Clinic. Journal of Women's Health, 19, 1843-1849. http://dx.doi.org/10.1089/jwh.2009.1800

[25] Möller, M.C., Rådestad, A.F., von Schoultz, B. and Bartfai, A. (2013) Effect of Estrogen and Testosterone Replacement Therapy on Cognitive Fatigue. Gynecological Endocrinology, 29, 173-176. http://dx.doi.org/10.3109/09513590.2012.730568

[26] Fasola, E., Anglana, F., Basile, S., Bernabei, G. and Cavallini, M. (2010) A Case of Labia Majora Augmentation with Hyaluronic Acid Implant. Journal of Plastic Dermatology, 6, 41-44. 
Scientific Research Publishing (SCIRP) is one of the largest Open Access journal publishers. It is currently publishing more than 200 open access, online, peer-reviewed journals covering a wide range of academic disciplines. SCIRP serves the worldwide academic communities and contributes to the progress and application of science with its publication.

Other selected journals from SCIRP are listed as below. Submit your manuscript to us via either submit@scirp.org or Online Submission Portal.
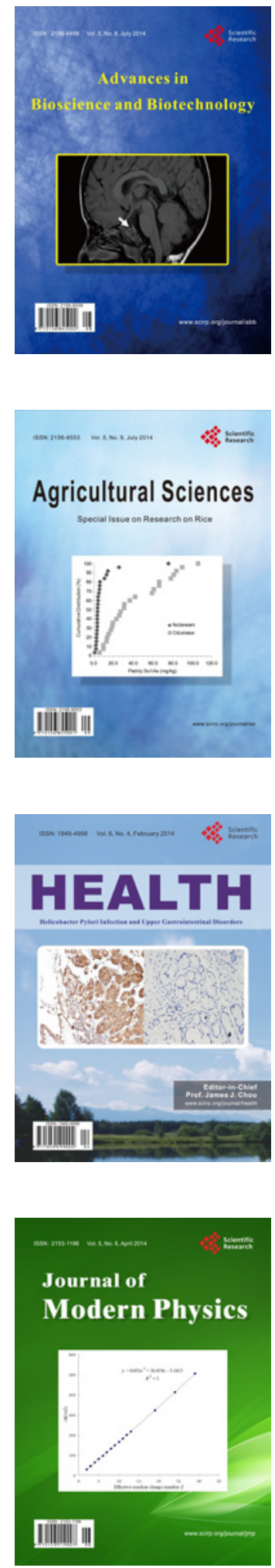
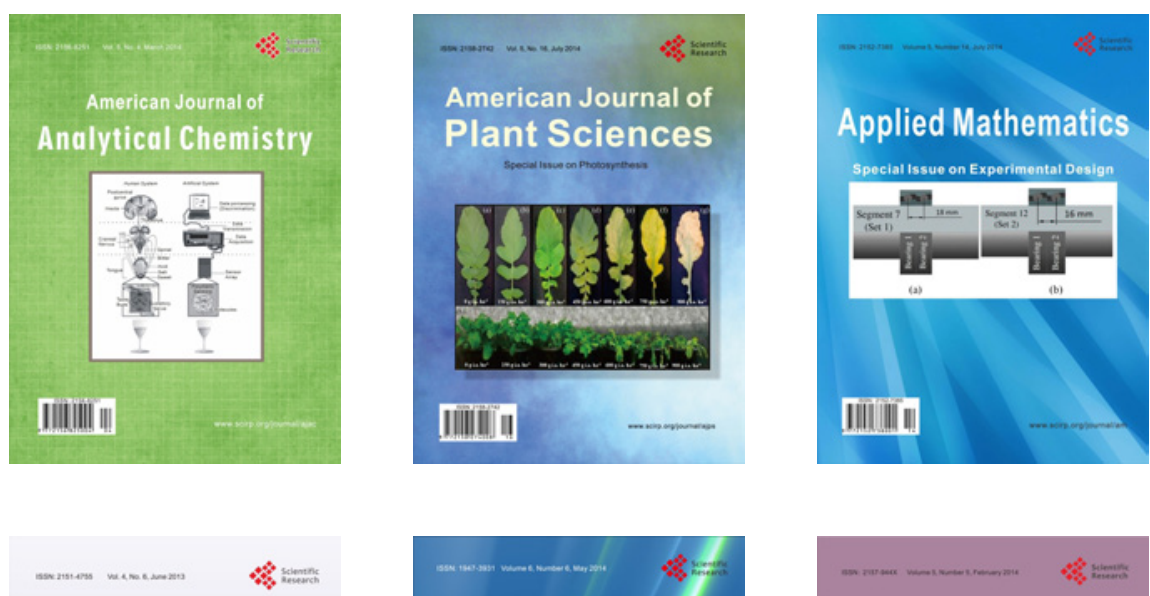

Creative Education
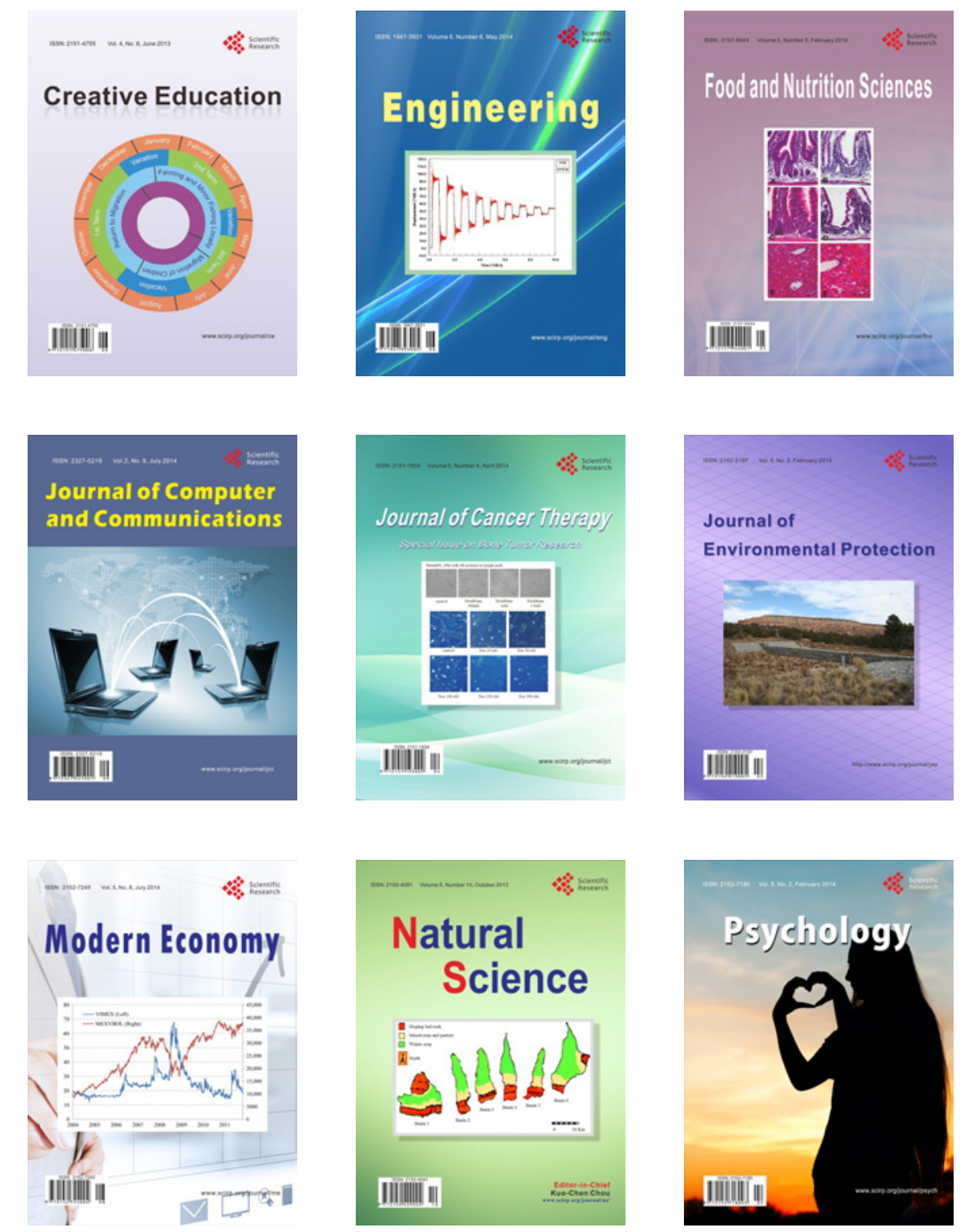